\title{
ZVYŠOVANIE KONKURENCIESCHOPNOSTI REGIÓNU NA ZÁKLADE UPLATŇOVANIA INOVATÍVNYCH PRÍSTUPOV K MARKETINGU - BRANDING NIAGARA REGION
}

\section{THE REGIONAL COMPETITIVENESS INCREASE BY THE IMPLEMANTATION OF THE INNOVATIVE MARKETING APPROACHES - BRANDING OF NIAGARA REGION}

\author{
ING. MARICA MAZUREKOVÁ \\ Inštitút ekonomických vied | Institute of Economic Sciences \\ Centrum vedy a výskumu Centre for Science and Research \\ Ekonomická fakulta Faculty of Economics \\ Univerzita Mateja Bela v Banskej Bystrici Matej Bel University Banska Bystrica \\ $\triangle$ Cesta na amfiteáter 1, 97401 Banská Bystrica, Slovak Republic \\ E-mail: marica.mazurekova@umb.sk
}

\begin{abstract}
Anotácia
Marketing území je jedným z nástrojov tvorby a udržania konkurenčnej výhody územia na základe využitia potenciálu územia (komparativnej výhody). Jeho cielom je rozvoj územia, využitie potenciálu trhu s ciel'om skvalitnenia života miestneho obyvatel'stva, vytvorenie kvalitného a trvalo udržatelného životného prostredia územia, ekonomický rast a sociálny rozvoj. Na rozvoj území v minulosti existovalo a v súčasnosti existuje viacero názorov a tieto sa prejavili následne i v uplatňovaní marketing území. Niektoré pristupy sú zamerané na tzv. neoklasický pristup k tvorbe marketingových stratégii s využitím tradičného prístupu k marketingu (založeným na využití marketingového mixu územia), ale vznikajú i nové pohl'ady na marketing území, ktoré sa zameriavajú na spotrebitel'a a jeho preferencie, lojálnost' a prinášajú efekty pre územie zhl'adiska dlhodobého účinku. V minulosti existovali aj názory, ktoré považovali marketing územi za neefektivny, v súčasnosti sú ale tieto názory prekonané. Tieto názory sa prejavujú najmä v obdobi krízy, ktorá môže byt ekonomickou krízou alebo iným druhom krízy (spôsobená pričinením človeka alebo náhodne). Naším cielom je vyvrátit' tento názor a poukázat' na nevyhnutnost' marketingu územia najmä v obdobi ekonomickej stagnácie, ale aj v obdobi konjunktúry s cielom zlepšenia konkurencieschopnosti územia. Pripadová štúdia z Kanady, ktorá má skúsenosti s inovatívnym prístupom k marketingu (Niagara Region) môže byt dobrým štartom a prikladom pre iné krajiny, napr. Slovensko alebo Česká republika.
\end{abstract}

\section{Kl'účové slová}

konkurencieschopnost' území, konkurenčná výhoda, komparativna výhoda, inovativny marketing územia, branding, place marketing

\section{Annotation}

Marketing of territories is one of major tools of the creation and sustainability of territorial competitiveness based on the implementation of territorial comparative advantage. Its goal is development of territory, the utilization of territorial market potential in order to improve the quality of life of local people, creation of sustainable living environment at the high qualitative level with the economic and social growth potential. The territorial development has been in the past influenced by several ideological streams and they have influenced the view on marketing of territories. Some approaches were based on the so called „,neoclassical "approach to the marketing strategies formation, which were based on the traditional marketing (by using of marketing mix of territory). However, there also exist new approaches to marketing of territories, which are focused on a supplier and his/her preferences, loyalty, and these approaches influence positively a territory in the long-term perspective. In the past, there existed opinions that marketing of territories is non-effective, but these ideas are overcome. This opinion is valid especially in the time of crisis, which could be 
economic crisis or other type of crisis (man made or inflicted). Our goal is to disconfirm this opinion and to point out at the necessity of territorial marketing especially during the period of economic stagnation or specific crisis in order to improve territorial competitiveness. The case study from Canada, which is experienced in the innovative approach to marketing (Niagara Region), might be a good starting point for other countries as for example Slovakia.

\section{Key words}

competitiveness of territories, competitive advantage, comparative advantage, territorial innovative marketing, branding, place marketing

JEL classification: $M 31$

\section{Úvod}

Konkurencieschopnost' sa v súčasnosti prejavuje nielen medzi ekonomickými subjektmi, ale aj medzi krajinami, regiónmi a mestami. Najmä v súčasnosti, ked’ je celosvetová ekonomika poznamenaná hlbokou ekonomickou krízou, ktorá sa prejavuje na všetkých kontinentoch v rôznej intenzite, je otázka konkurencieschopnosti a nových pohl'adov na ekonomiku, jej rozvoj vel'mi aktuálna. Inovatívnost', kreativita, snaha zvýšit' konkurencieschopnost', to sú momentálne jedny z najviac používaných tém v ekonomike a je zaujímavé, že mnohé krajiny, ktoré boli schopné tieto nové cesty k ekonomickej konsolidácii a skvalitneniu života svojich obyvatel'ov absolvovat', resp. s nimi začali, napr. škandinávske krajiny v Európe, dosahujú výrazný úspech. Ciel'om práce je objasnit' a zdôvodnit' nové a kreatívne prístupy $\mathrm{k}$ marketingu území a vysvetlit' princípy konkurencieschopnosti a nutnost' inovatívneho prístupu k marketingu, predovšetkým vysvetlit' niektoré možnosti využívania place marketingu, place brandingu v územiach nielen na základe existujúcej teórie, ale najmä praktických skúseností z Kanady - Niagara Region a tvorby Brand Niagara.

Metódou zvolenou v prístupe $\mathrm{k}$ tejto štúdii je prípadová štúdia, ktorá bola študovaná a získaná na základe výskumu v Kanade a cielených rozhovorov (primárny výskum) s predstavitel'mi Niagara Region, stretnutí marketingových odborníkov počas príprav Brand Niagara, rozhovorov s odborníkmi z praxe i akademikmi (University Waterloo a Brock University) a predstavitel'mi CTC (Kanadskej turistickej komisie). Sekundárny výskum bol realizovaný počas študijného pobytu $v$ Kanade $\mathrm{v}$ priebehu pôsobenia na University of Waterloo. Sekundárny výskum bol zameraný na preštudovanie správ a marketingových štúdií o Niagara Region ako i materiálov a štúdií, ktoré boli dostupné nielen na internete, ale aj v knižnici menovaných univerzít.

\section{Teoretické vymedzenie konkurencieschopnosti}

Princíp konkurencieschopnosti v ekonomike a manažmente sú založené na ekonomických teóriách Adama Smitha, Davida Ricarda, Schumpetera, Portera, Hunta, ktorí významne prispeli k teórii konkurencieschopnosti. Hunt (2000) ako autorka tzv. „Resouce-Advantage Theory (RA), teórie konkurenčnej výhody založenej na zdrojoch, prispela $\mathrm{k}$ rozvinutiu d’alších názorov na teóriu konkurencieschopnosti a novú teóriu konkurencieschopnosti v marketingu, manažmente, podnikaní a ekonomike. Resource-advantage theory (RA) je založená na teórii konkurencieschopnosti a inovácií, ktorú rozpracoval Schumpeter a ktorá bola neskôr zahrnutá aj do marketingovej teórie ako tzv. Heterogénna teória dopytu. Zdôrazňovala význam segmentácie dopytu podporujúcej rast konkurenčnej a komparatívnej výhody. Teória konkurencieschopnosti založenej na zdrojoch, na rozdiel od neoklasickej teórie maximalizácie úžitku (Pareto, Walras), rozvinula myšlienku, že napriek snahe dosiahnutia maximalizácie zisku, firmy musia čelit’ problému nedostatočnej znalosti trhu a jeho faktorov ako sú napr. konkurenti, trhové segmenty, dodávatelia a technológie. Tieto faktory nie sú len dôležitými zdrojmi komparatívnej výhody, ale sú aj zdrojmi vedomostí, organizačnej kultúry, procesov a organizačných štruktúr. 
Konkurencieschopnost' možno definovat' ,ako schopnost' podnikov, odvetví, regiónov, národov a nadnárodných regiónov generovat' vysokú úroveň príjmov a zamestnanosti (Skokan, 2004, s. 61). Viacerí autori ako Kadeřábková (2003), Cellini a Soci (2002) pokladajú konkurencieschopnost' za najdôležitejší faktor úspešnosti. OECD (1997) chápe konkurencieschopnost' ako „schopnost' regiónu produkovat' výrobky a služby, ktoré sa predávajú na medzinárodných trhoch a tvorit' vysoké a udržatel'né príjmy za vysokej zamestnanosti. V definícii Skokana (2004, s. 61) sa prejavuje nielen ekonomický aspekt ziskovosti, ale aj udržatel'nost' a tvorba pracovných miest, zlepšovanie životnej úrovne obyvatel'stva, koncepty, ktoré majú i mikroekonomický charakter i makroekonimcký charakter. Princípy konkurencieschopnosti, komparatívnej a konkurenčnej výhody diskutovali aj Mankiw (2009), Varian (2010), Samuelson a Nordhaus (1995), Henderson et al. (1991), Holman (2002), Frank (1995), Nezval (2004), atd'. Význam trhu a konkurencieschopnosti napr. zdôraznil Fuchs (2001, s. 18), ktorý konštatoval, že „trh sa stáva centrom celého hospodárskeho systému, sprostredkuje styky jednotlivých subjektov, je nástrojom koordinácie hospodárstva.“

Konkurencieschopnost' možno všeobecne spájat' s ekonomickým rastom v interaktívnom procese spoločenských, politických a inštitucionálnych zmien. Multidisciplinárny prístup k štúdiu konkurencie sa prejavil aj v myšlienkových prúdoch a epistemologickom prístupe $\mathrm{k}$ štúdiu konkurencie, kde sa prejavili najmä tieto tri prúdy:

- štúdium konkurenčnej výhody/cenová konkurencia

- štúdium konkurenčnej výhody z manažérskej perspektívy

- štúdium konkurenčnej výhody zo sociálneho a kultúrneho hl'adiska

Konkurencieschopnost' je nutné ponímat' $\mathrm{z}$ dvoch uhlov pohl'adu - v prvom rade, čo konkurencieschopnost' je, ale ktoré faktory majú vplyv na konkurencieschopnost'. Konkurencieschopnost' sa prejavuje medzi jednotlivými firmami, krajinami, finálnymi výrobkami, službami a pod. Za základ stratégie konkurencieschopnosti považoval Porter (1980) 5 síl, ktoré charakterizoval ako konkurenčné prostredie, dopyt, ponuku, vstupy, rivalitu medzi existujúcimi firmami a nebezpečenstvo substitúcie (Schéma 1).

Schéma 1: Sily konkurencieschopnosti podl'a Portera (1980).

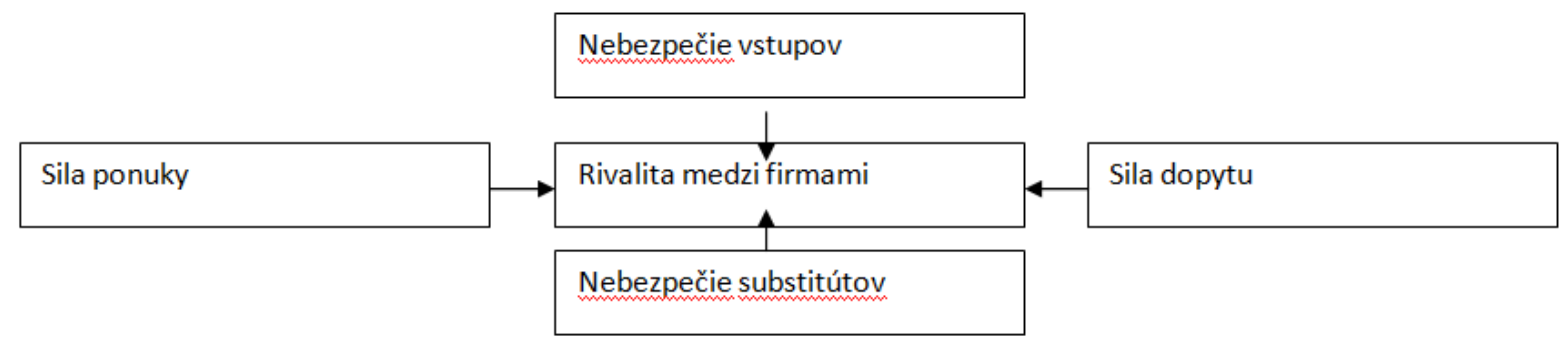

Zdroj: Porter, M. 1980. Competitive Strategy.

Z územného hl'adiska, na základe charakteristík konkurencieschopnosti, ktoré definoval Porter (1996,

s. 166) je ekonomická konkurencieschopnost’ územia založená na týchto podmienkach alebo silách:

- faktorové podmienky (pozícia krajiny alebo územia z hl'adiska faktorov produkcie - práca, pôda a kapitál), kde zahrnul z hl’adiska kapitálu i l’udský kapitál, t.j. vzdelaná pracovná sila a tiež infraštruktúru,

- podmienky dopytu (domáci dopyt po výrobkoch a službách v území),

- podporné činnosti,

- stratégia, štruktúra a rivalita (systém riadenia, manažment, ktorý sa využíva na domácom i zahraničnom trhu).

Porter definoval konkurencieschopnost' v podmienkach výroby, ale princípy konkurencieschopnosti, ktoré definoval sú uplatnitel'né aj na územnom princípe pri definovaní konkurencieschopnosti území a môže íst' o rôzne typy území, ktoré si v súčasnosti konkurujú, napr. kontinenty, krajiny, regióny alebo mestá. Vzhl'adom na územie, ktoré je súhrnom pôsobenia viacerých firiem, je marketingové hladisko komplexným produktom vytvárajúcim dopyt na základe ponuky (prírodné faktory, umelo 
vytvorené, endogénne, exogénne). V rámci produktu územie sa realizujú procesy a pôsobia sily ako $\mathrm{v}$ prípade firiem. $\mathrm{V}$ územiach dochádza $\mathrm{k}$ rivalite medzi jednotlivými firmami, ale táto rivalita existuje i navonok, medzi územiami, kde sa prejavuje nebezpečie existencie substitútov. Sila dopytu závisí od viacerých faktorov, napr. od ceny, alokácie územia, hlavne motivácie subjektov dopytu, ale i marketingovej stratégie územia.

Prvá sila konkurencieschopnosti - nebezpečie vstupov predstavuje obmedzenia a bariéry, ktoré zamedzujú konkurencieschopnost' - napr. distribučná siet', infraštruktúra, politika vlády alebo samosprávy, bariéry uplatňovania efektívnej marketingovej politiky, produktová diferenciácia, kapitálové náklady a pod.

Tieto faktory ovplyvňujú cenovú konkurencieschopnost' a dôraz sa kladie najmä na produktovú diferenciáciu a podiel na trhu. V rámci produktu územie je preto komplikované kontrolovat' a riadit' všetky vstupy a zabezpečit' optimálnu kooperáciu zainteresovaných subjektov územia, subjektov verejného a súkromného sektora a kooperáciu miestneho obyvatel'stva, ktoré je zdrojom nielen pracovných síl a vytvára hodnoty pre územie, ale je aj spolutvorcom produktu územie, napr. svojím podielom na ekonomických a sociálnych aktivitách v území a na tvorbe pozitívneho imidžu územia.

Porter (1990) v knihe „Konkurenčná výhoda národov “ uvádza, že úspech nezávisí len na stratégii a pozícii, ale aj na vplyve prostredia a to nielen vnútorného, ale aj vonkajšieho. Prostredie môže vytvárat' často i negatívne externality, napr. krízy. Regióny, územia sú teda zdrojom úspechu, pretože poskytujú inovatívne, dynamické a konkurencieschopné prostredie. Okrem štyroch faktorov úspechu území (faktorové podmienky, dopyt, podporné činností, stratégia, štruktúra dopytu a rivalita), ktoré už boli spomenuté, zdôraznil aj dve podmienky, ktoré sú vel'mi dôležité pre konkurencieschopnost' a tými sú šanca a vládna politika. Schéma 2 znázorňuje spolupôsobenie týchto síl na konkurencieschopnost’ územia.

\section{Schéma 2: Spolupôsobenie síl na konkurencieschopnost’územia}

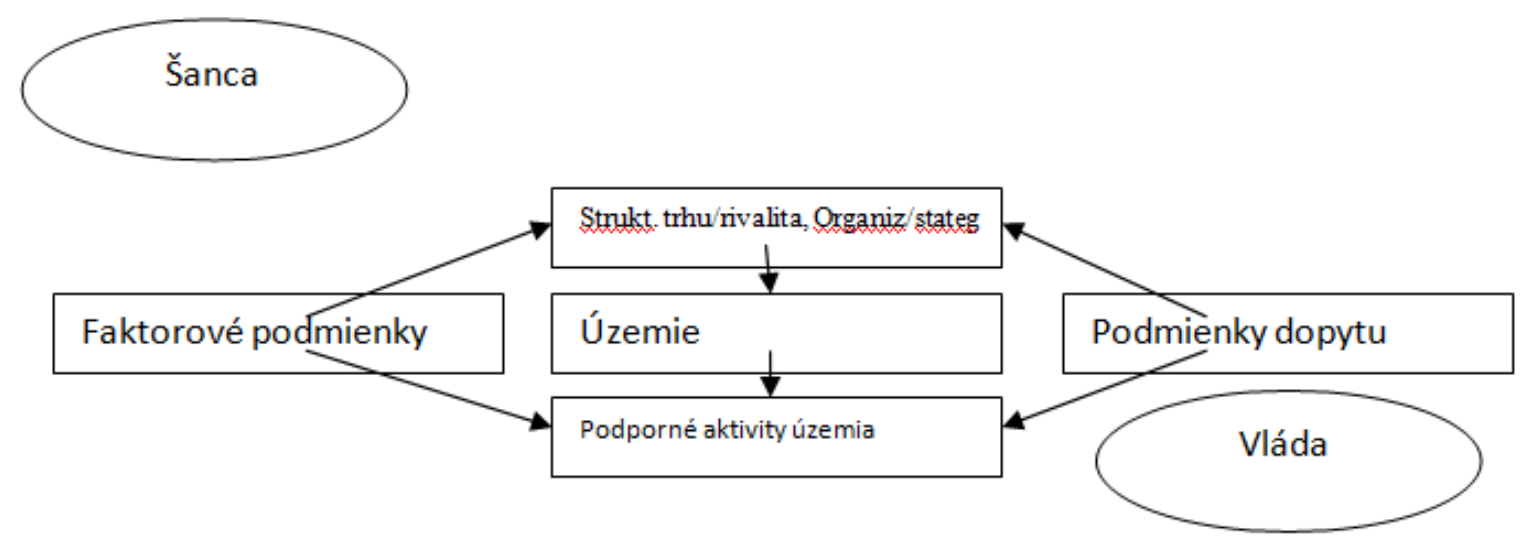

Zdroj: Porter (1990).

K d’alším faktorom, ktoré vplývajú na konkurencieschopnost' území patrí napr. existujúce prírodné prostredie a geografická charakteristika územia, kultúrne a historické zdroje, kapitálové zdroje (napr. finančný a l’udský kapitál), infraštruktúra. Dopyt po produkte územie je závislý od rozsahu a štruktúry trhu, charakteru a štruktúry ponuky a motivácie spotrebitel’ov, ktorými sú nielen obyvatelia, ktorí na území žijú a pracujú, ale aj návštevníci územia, ktorých motívy návštevy a spotreby produktu územia môžu byt' založené na podnikatel'ských úmysloch, resp. vol’nočasových aktivitách (cestovný ruch a pod.). Pri uplatňovaní faktorov rastu konkurencieschopnosti by mali napomáhat' podl'a horeuvedenej schémy a Porterovej koncepcie i šanca a vláda, čo môžeme chápat' aj ako využitie inovatívneho prístupu a nových myšlienok, napr. pri tvorbe konkurencieschopnej marketingovej stratégie alebo tzv. place brand stratégie za podpory miestnej regionálnej samosprávy, ale i spôsob riadenia a politiky zo strany štátu, územnej samosprávy a jej prínos k riešeniu 
ekonomických problémov územia. $Z$ toho dôvodu by sme chceli zdôraznit' význam tzv. place brandingu, alebo brandingu území, ktorý začal za posledné desat'ročie zaujímat' nielen marketérov, geografov, ekonómov, ale i politikov. Mnohé krajiny začali venovat' čoraz väčšiu pozornost' dôvodom, prečo sú faktory úspechu často spájané s územiami, miestami, kde sa nachádzajú úspešné firmy, vzdelávacie inštitúcie, zdravotnícke zariadenia, moderná dopravná infraštruktúra, uznávaný výskum, vývoj a kde sa sústred’ujú talentovaní l’udia a prichádzajú návštevníci, noví investori.

Crouch a Ritchie (2003) stanovili kroky k úspechu územia v konkurenčnom boji podla nasledovnej schémy (Schéma 3).

\section{Schéma 3: Kroky $k$ úspechu a konkurencieschopnosti územia}

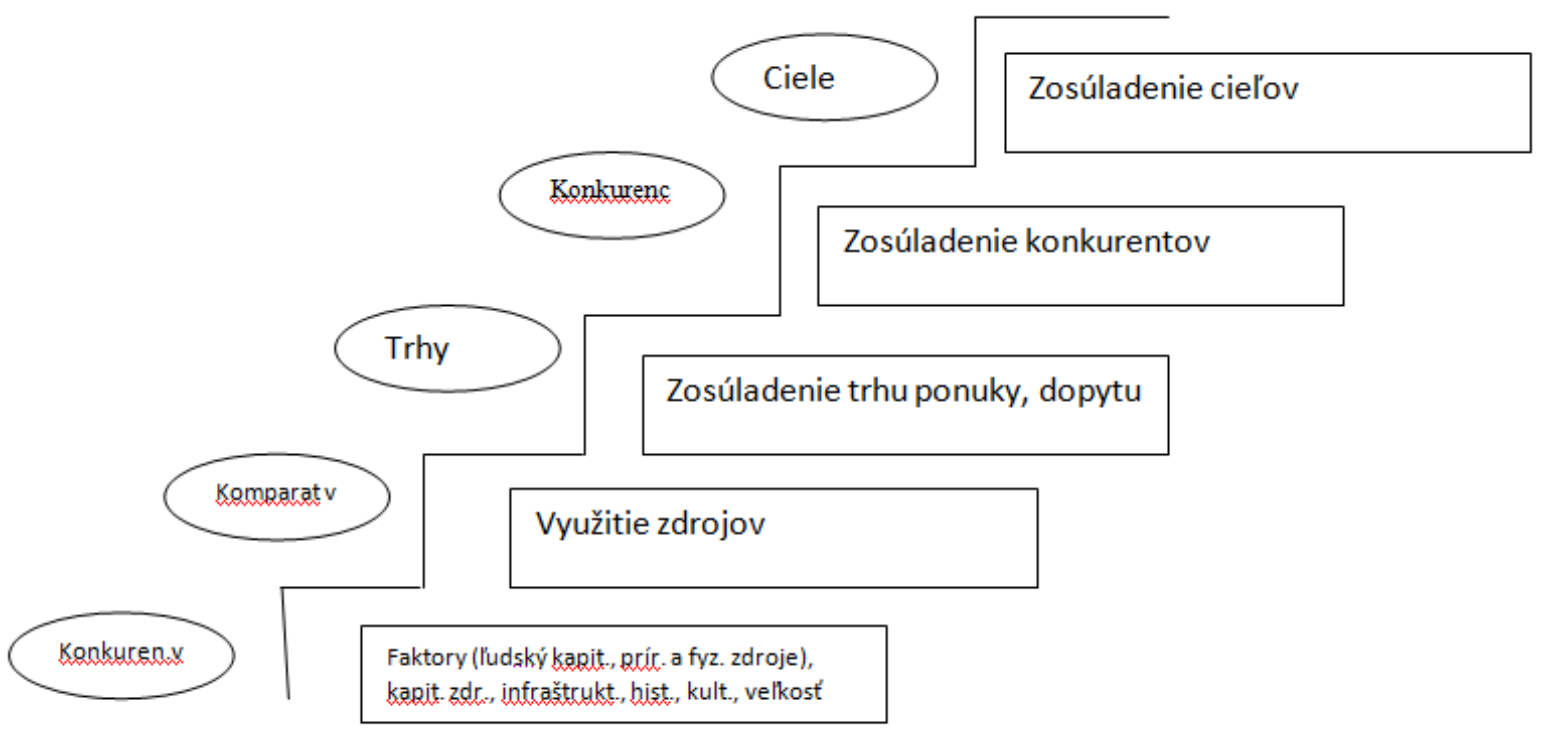

Zdroj: Crouch, Ritchie (2003).

Crouch a Ritchie (2003) vo svojom modeli konkurencieschopnosti území došli k záveru, že dôležitá je nielen existencia zdrojov konkurencieschopnosti, ale aj ich využitie a procesy, ktoré vúzemí v procese využitia zdrojov prebiehajú, t.j. napr. marketingová činnost', manažment, strategická spolupráca súkromného a verejného sektora a pod. Dôležité sú nielen zdroje komparatívnej výhody, t.j. kapitálové zdroje, infraštruktúra, prírodné zdroje, l'udský kapitál, ale aj ich využitie, čo zdôraznil aj Smeral (1996), ale aj Vaňová (2006) a pod. Manažérske procesy ako marketing, manažment, ale i branding, financovanie, spájanie partnerov v partnerstvách pri riadení a rozvoji území, prenos inovatívnych technológií a procesov riadenia, vytváranie inteligenčných centier a klastrov sú novými alebo inovovanými prístupmi k modernému riadeniu území s ciel’om ich lepšieho ekonomického rozvoja a rastu blahobytu obyvatel'ov. Jedným z možných nových prístupov k marketingu území a manažmentu je branding, ktorú by sme chceli vysvetlit' najmä z dôvodu prepojenia brandingu území, place brandingu ako inovatívneho prístupu k marketingu území.

\section{Inovatívny prístup $\mathrm{k}$ marketingu územia - place branding}

Inovatívne aktivity a konkurencieschopnost' sú ovplyvnené vedomostnou ekonomikou a tlakom na prenos vedomostí do ekonomiky, spoločnosti. Konkurencieschopnost' a inovácie sú prepojené, nakol'ko inovácie sú základom konkurencieschopnosti. Nové znalosti a vedomosti sú konkurenčným nástrojom inovácií v novej post-kapitalistickej spoločnosti založenej na znalostnej ekonomike. Drucker (1993, s. 38) poznamenal, že “vedomosti sú významným zdrojom v súčasnosti”; ale dôležité nie je len existencia vedomostí, ale ich použitie v prospech firiem, regiónov a krajín. Postupný prechod spoločnosti a ekonomiky $\mathrm{z}$ obdobia Fordizmu a post-Fordizmu znamenal prechod od industriálnej spoločnosti a ekonomiky na ekonomiku založenú prevažne na službách a na procesoch, riadiacich chod jednotlivých činností vo forme manažmentu, marketingu, produktovej, procesnej a marketingovej inovácii, ale i inštitucionálnej inovácii. 
Z dôvodu, že ciel'om našej práce je diskusia o konkurencieschopnosti na základe uplatňovania inovatívnych prístupov $\mathrm{k}$ marketingu, pokladáme prístup inovatívnosti na inštitucionálnej úrovni zamerané na nový prístup $\mathrm{k}$ marketingu území sa východisko pre diskusiu a objasnenie nového prístupu k marketingu území, ktorý môžeme nazvat' place (destinačný) branding alebo place (destinačný) marketing, kde je dôležité vysvetlenie tohto konceptu a hl'adanie podobných príkladov úspešného marketingu území, ktorý bol založený na využívaní konkurenčnej výhody území.

Konkurenčnú výhodu podla niektorých autorov (Asheim, Isaksen, 1997; Porter, 1998) je možné vytvorit' na základe územne lokalizovaných a často neekonomických faktorov. Ak je konkurenčná výhoda zohl’adnená v strategickom marketingovom pláne a je $\mathrm{v}$ súlade $\mathrm{s} \mathrm{s}$ víziou rozvoja územia a „snaží sa dosiahnut' strategickú výhodu tak, že svoju ponuku pevne umiestni v mysliach zákazníkov v porovnaní s ponukou konkurencie (Vaňová, 2006, s. 83), má predpoklad zabezpečit' úspech územia v konkurenčnom boji. Existencia konkurenčnej výhody a najmä jej využitie rozhoduje o úspešnosti regiónu. Definíciu konkurenčnej výhody možno chápat' na základe Porterových generických statégií, ktoré vyzdvihli vodcovstvo v stratégii, diferenciáciu a špecializáciu (1985, s. 11). Konkurenčná výhoda sa zameriava na tri ciele - uspokojovanie potrieb zákazníkov alebo v prípade územia užívatel’ov územia, efektívne využívanie zdrojov územia, tvorba pozície v rámci určitej sietí hodnôt, kde je nutné skúmat' aj motiváciu užívatel'a územia, akú hodnotu očakáva od územia, kde je možné očakávat' i špecifické produkty, služby, kvalitné životné prostredie, kvalitnú infraštrukúru, výhodné podmienky na podnikanie, pozitívny imidž a pod.

Porter (1998, s. 78) tvrdí, že „stále komparatívne výhody v globálnej ekonomike sú založené na miestnych princípoch - vedomosti, vzt'ahy, motivácie - to je vlastne to, čo konkurencia môže t'ažko kopírovat"“. Na týchto princípoch je založená aj celá koncepcia brandingu zameraná na územné celky a nie na výrobky, hoci pôvod tejto koncepcie je vo výrobe a medzi prvými autormi, ktorí sa zaoberali brandingom vo výrobe boli napr. Aaker, Kapferer, Keller a pod. Tvorba hodnoty prostredníctvom procesu inovatívneho marketingu - brandingu a tvorba nadhodnoty, tzv. brand equity pre územie je prínosom nového prístupu k marketingu, plánovaniu a riadeniu územia. Thode a Maskulka (1998, s. 382) definujú brand equity ako situáciu, ked’ je „producent schopný predat' za prémiovú cenu“. Pôvodne bol tento termín vytvorený v účtovníctve. V marketingu sa chápe tento koncept ako vzt’ah medzi zákazníkom a poskytovatel'om produktu, služby, resp. napr. vzt'ah užívatel'a územia k produktu územie, ak by sme diskutovali o území a brandingu územia.

Brand equity je možné vysvetlit' na základe neoklasického prístupu a tzv. vzt'ahového prístupu, ktorý je založený na mikroekonomickej perspektíve a použití nástrojov marketingového mixu, napr. produkt územia, komunikácia, l’udský kapitál, cena a pod., avšak prístup vytvorenia vzt’ahu k územiu je inovatívny prístup k marketingu, ktorý zdôrazňuje nutnost' orientácie marketingu na potreby zákazníkov, t.j. užívatel'ov produktu územie, ktorí môžu byt' obyvatelia, investori, potenciálni investori, návštevníci a pod. Z toho dôvodu je omylom, ked’ sa branding spája len s tvorbou značky a loga ako u výrobkov, pretože v územiach je branding spojený s ovel’a širšími súvislost’ami, ide o procesy , vzt'ahy, vytváranie nielen obrazu destinácie, ale aj jeho skutočné naplnenie, či vo vzt'ahu k obyvatel'om územia, existujúcim a potenciálnym investorom, návštevníkom. Existencia konkurencie medzi územiami núti jednotlivé územia inovovat' svoje marketingové stratégie, skvalitňovat' podmienky podnikania pre podnikatel'ské subjekty a podmienky života miestnych obyvatel'ov. Z marketingového hladiska je dôležitá tvorba imidžu, diferenciácia a tvorba konkurencieschopnej marketingovej pozície na trhu území, prenos dobrých príkladov z iných regiónov a ich skúseností (benchmarking). Príklady dobrej praxe a porovnanie prístupu $\mathrm{v}$ iných krajinách $\mathrm{k}$ inovatívnemu marketingu území, miest a regiónov môžu mat' pozitívny vplyv na konkurencieschopnost' aj v iných krajinách, ak budú správne využité a pochopené. Jedným z takýchto pozitívnych príkladov praxe z Kanady je tvorba Brand Niagara a place marketing a place branding prístup, čo dokumentujeme v prípadovej štúdii získanej priamo v Niagara Region, Kanada. 


\section{Brand Niagara a prípadová štúdia z Kanady, Ontário (Brand Niagara and case study from Canada, Ontario)}

The aim of the study was to obtain the information on branding in Niagara Region based on collection of secondary and some primary data. We tried to explain the reasons of branding in Niagara Region focused especially at product innovation. Based on two conducted surveys - Travel Activity and Motivation Survey (TAMS) from 2006 and a "return-to-sample" survey from 2007, we defined which tourism products were the most decisive in a region to be included into their branding strategy and in Brand Niagara Original.

In order to demonstrate the approach to the branding strategy preparation in Niagara Region, we shed light on the process of preparation of brand, logo, brand identity identification and co-operation of stakeholders in the region. The source of secondary data was the existing Niagara Original Brand as well as sources on internet. A case study was used with the aim to present specific characteristics of the region. Our research was conducted during multiple visits of Niagara Region and participation at the meetings of marketing experts involved in the preparation of Niagara Original Brand and discussions with experts from tourism industry and academics. This focus group methodology as a primary tool method enabled to explore deeper the developments and concepts behind the Niagara Original Brand process. The combination of primary and secondary research methods allowed us to obtain a broad picture of the process of brand creation and especially the outcome of it - Niagara Original Brand and product brand innovation opportunities for this region.

Niagara Region is situated at the Niagara Penninsula consists of 12 municipalities: Niagara Falls, Niagara-on-the-Lake, Fort Erie, St. Catharines, Port Colborne, Thorold, Weinfleet, Welland, West Lincoln, Pelham, Lincoln. In tourism product portfolio of this region are offered such products as wine tourism products (Niagara Winery Route), culinary tourism, cultural tourism (Shaw Festival), but this region is also familiar for such attractions as Casino Niagara, Welland Canal (technical attraction serving as the transportation facility as well as tourism attraction), wedding tourism product (Honey Moon Capital of the World). The region offers also historical sites (battleground between the United States and Great Britain in 1812, etc.). The competitive advantage is based on the proximity to the U.S.A. The icon of region is Niagara Falls; and in the concept of branding it means the place or characteristics, which is the most authentic and typical for the brand identity identification. The identity of this region has been described as "abundant, authentic, beginnings, history, inventive, oneof-a kind, rare, surprising, unexpected, unique, vivid, and accessible."

Creation of brand image and brand identity requires a consistent and systematic approach and may "take many years to establish and brand image, establish name recognition and develop strong awareness of a destination or product (Morgan, Pritchard, Piggot, 2003). Success could be not only trend and novelty; it could be a loyalty to the traditional values and attributes implied in new marketing strategies and branding. A good example of a country with traditional values, which uses this strategic advantage in marketing, is Switzerland. Niagara Region in Canada, similarly as other regions or countries with tourism traditions, focused the attention at preparation of a competitive marketing strategy, product innovation and Brand Niagara Original is the result.

Concerning the innovation of tourism products in the existing marketing strategies and based on the above mentioned surveys - Travel Activity and Motivation Survey (TAMS) from 2006 and a "returnto-sample" survey from 2007, we obtained the following secondary research outcome. The a priori and a posteriori segmentation of the marketing products offered in marketing strategy of region confirmed a necessity of innovation of some tourism products, which have been later also included into the Brand Niagara Original.

The results of survey pointed at the fact that dinning, visiting local culinary attractions, organizing events with culinary content are very perspective and popular among visitors. Similarly as the countries with wine industry, orchards, natural beauties, food and wine festivals (France, Spain, 
Portugal, Austria, Australia) also Niagara region has a potential for development of such a product strategy. This region is familiar for plentiful wineries (34 in Niagara Escarpment and 30 in Niagaraon-the-Lake), specialized themed international dining facilities, golfing facilities, etc. The result of research highlighted that the most popular activity is experiencing of local food (55,7-\%). The reasons for tracing the patterns and characteristics of visitors' motivation and appeal were to explore the most perspective products and find out if the branding strategy outlined in Niagara Region corresponds to research results. One interesting fact, which may be also an explanation why culinary tourism is a possible innovative approach in a future in marketing, is the existence of one important target group, seniors. $56,4-\%$ of respondents agreed that Niagara Region is a suitable destination for seniors. To support the idea of importance of culinary tourism as a product suitable to put into the innovative marketing and branding strategy, over 58 million people of North American continent are 55 and older and in 2025 there will be 85 million seniors at the North American continent. Ontario province recognized the importance of culinary tourism products as the innovative approach to tourism marketing strategy and developed Wine and Culinary Tourism Action Plan, which was designed to support a new potential product and support this project also financially. One of the most important goals was to recognize Ontario internationally as a marketing brand destination in wine and culinary tourism. On base of this development, a very competitive branding process and brand of the region has to be established, which evoked the start of the process of Brand Niagara Original. Moreover, in Niagara Region was necessary to form strategic partnerships and alliances and prepare conditions for multiple financing from private and public sources.

Prior to the creation of Brand Niagara Original, a strong research and preparation of the whole process of marketing strategy forming took place. There were conducted 20 stakeholder interviews and 7 municipal group interviews, 3 workshops and the focused group interviews with 15 tourism experts and business leaders. Additionally, primary research method was used in interviewing of 1650 Canadian and international visitors to Niagara Region. A result of this long-term preparation of marketing activities is a competitive strong brand. The creators of Brand Niagara Original stated that brands help us to improve product development, marketing strategies, partnerships and communication programs and during crises and economic turmoil they enable to improve trust in tourism products and authentic experiences. At the end of this discussion it is crucial to point out at the process of brand of tourism destination creation and its difficulty, especially a problem with the co-operation of participating partners and community in fulfilment of branding strategy. The case study used in this research might be a good example for other regions and countries interested in preparation of successful marketing strategies by the implementation of branding (benchmarking approach). Branding is not new to the marketing theory and practice. It has been used in production setting for almost 50 years and in tourism destination marketing for about 15 years, but the principles of branding in tourism are still not fully understood.

For this reason, in conclusion, we tried to explain basic concepts of destination branding and summarize the impact of branding and the innovative approach to process and product marketing in tourism destinations. Marketing management and branding requires the co-operation of stakeholders in a destination and also support from the local people and government. A case study from Niagara Region as one example of a successful branding process and brand implication in a region or a country brought up some new evidence and findings in marketing and branding practice in the world, in this case in Canada, Ontario. Niagara Region case was a success and Brand Niagara has helped the region to improve its image and economic outcomes. However, the preparation of Brand Niagara required enourmous amount of time, leadership, research activities and co-operation with the local communities. Creation of brand is one side of the process, but the implementation of brand in real setting...so called "living the brand" might be a really demanding journey. Niagara Region is an example of the positive outcome.

\section{Diskusia, hlavné výsledky a záver}

Záverom zhrnieme niektoré myšlienky, ktoré považujeme za dôležité z hl'adiska prepojenia konkurencieschopnosti, inovácie a jej uplatňovania na územnom princípe, napr. na regionálnej úrovni. 
Inovácie a chápanie a a videnie javov novým, netradičným spôsobom ako doteraz je základom tzv. novej ekonomiky alebo ekonomiky založenej na vedomostiach a ich prenose do praxe. Objavovat' nové zdroje bohatstva a rastu a zosúladit' ich s platnými koncepciami a teóriami rastu a konkurencieschopnosti a tiež nájst' hodnoty, ktoré sú často i nemateriálneho charakteru (napr. znalosti l'udí), ale ktoré sa prejavujú rastom hodnôt i v materiálnom poňatí je nel'ahké. Je pomerne t’ažké i stanovit' a kvantifikovat' nakol'ko nové znalosti l'udí napr. obohatili určitý územný celok a ako sa podielajú na jeho ekonomickom a sociálnom raste. Je nepopieratel'né, že nové prístupy, znalosti, nový spôsob videnia vecí i hospodárskej praxe je zdrojom bohatstva a tieto myšlienky už boli dávno spomínané autormi, ktorí žili v dve-tri storočia pred nami. Evolúcia týchto myšlienok a potvrdenie mnohých názorov v súčasnej hospodárskej praxi i spoločenskom živote naznačujú, že vývoj v l'udskej spoločnosti a myslenia je nutné vidiet' ako proces, ktorý je založený na stálom učení sa a nových trendoch.

Teória konkurencieschopnosti zdôraznila, že nielen maximalizácia zisku, ale aj iné zdroje ako sú vedomosti, organizačná kultúra firiem, procesov a organizačné štruktúry firiem sú významným zdrojom bohatstva a konkurenčnej výhody a zároveň i väčšiu orientáciu na spotrebitel'a, jeho myslenie a preferencie. $Z$ toho dôvodu sú vedomosti, vzt’ahy a motivácia považované za zdroje konkurenčnej výhody, ktoré sú t’ažko napodobitel'né, často majú nehmotný charakter a t'ažko sa ekonomicky kvantifikujú, ale výrazne prispievajú $\mathrm{k}$ rastu konkurencieschopnosti nielen v podnikoch, ale aj $\mathrm{v}$ územiach. Tieto koncepcie boli zahrnuté i do inovatívneho prístupu k marketingu území, brandingu území, place brandingu, ktorý považujeme za inovatívny prístup $\mathrm{k}$ marketingu na základe uplatnenia princípov diferenciácie a výnimočnej pozície na trhu území. Zopakujeme na záver opät' slová Ploga (2004), ktorý konštatoval, že „bez dobrého brandingu aj ten najdokonalejší proces tvorby marketingovej pozície zlyhá““.

Proces tvorby Brand Niagara bol poznačený dlhodobou fázou príprav a hlavne nutnost'ou porozumiet' základným princípom place marketingu a brandingu. Niagara Region je jedna z najviac navštevovaných územných oblastí, regiónov v Kanade a za svoj úspech vd’ačí nielen výnimočným prírodným scenériám a danostiam, ale aj inovatívnemu prístupu $\mathrm{k}$ marketingu regiónu a úspešnej tvorbe produktu územia a jeho ponuke na domácom i medzinárodnom trhu. Výnimočnost' územia, ktorá bola úspešne spojená $\mathrm{s}$ autenticitou a s inovatívnymi manažérskymi a marketingovými metódami je možné znásobit' prostredníctvom takých nástrojov riadenia ako je place marketing a branding. Niagara Region je jedným z príkladov, kde je možné čerpat' inšpiráciu a získat' cenné poznatky i pre iné územia a regióny.

\section{Literatúra}

[1] ASHEIM, B.T., ISAKSEN, A.. Localisation, Agglomeration and Innovation. Towards Regional Innovation Systems in Norway? European Planning Studies, 1997, 5(3), s. 299-330.

[2] CAMAGNI, R. et al. On the concept of territorial competitiveness - sound or misleading? Urban Studies, 2002, 39, s. 2395-2411

[3] CELLINI, R; Soci, A. Pop competitiveness. BNL Quarterly Review, 2002, č. 220, s. 71-101.

[4] CROUCH, G. I.; Ritchie, J. R. B. The Competitive Destination: A Sustainable Tourism Perspective. Cambridge: CABI Publishing, 2003. ISBN 0851996647.

[5] DRUCKER, P. F. 1993. Post-Capitalist Society. Butterworth, Heinemann, NY. In Johanesson, J. A., Olsen, B.; Lumpkin, G. T (2001). Innovation as newness: what is new, how is new, and new to whom? European Journal of Innovation Management, Vol. 4, No. 1, s. 20-31.

[6] FRANK, R. H. Mikroekonomie \& chování. 1995. Praha: Nakladatelství Svoboda, 1995. 765 s. ISBN 80-205-0438-9.

[7] FUCHS, K. Mikroekonomie. UMB: Občianske združenie Financ, 2001. ISBN 80-968702-3-8. $181 \mathrm{~s}$.

[8] HENDERSON, J. V. et al. Principles of Microeconomics. Lexington: D.C. Heath and Company, 1991. ISBN 0-601-144492-4, s. 630.

[9] HOLMAN, R. Mikroekonomie. Praha: C. H. Beck, 2002. 591 s. ISBN 80-7179-737-5. 
[10] HUNT, S. D. A general Theory of Competition. California: Thousand Oaks: Sage Publications, 2000. ISBN 0-7619-1729-2.

[11]KADEŔÁBKOVÁ, A. Základy makroekonomickej analýzy: rust, konkurenceschopnost, rovnováha. Praha: Linde, 2003. 175 s. ISBN 80-861-3136-X.

[12] MANKIW, G. N.Zásady ekonomie. Praha: Grada Publishing, 2009. ISBN 80-7169-891-1.

[13] MORGAN, N. L., PRITCHARD, A.; PRIDE, R. Destination Branding: Creating the Unique Destination Position. Oxford: Butterworth-Heinemann, 1999. ISBN 0978075069697.

[14] NEZVAL, P., TULEJA, P. Mikroekonomie. Karviná: SU OPF, 2004. ISBN 80-7248-235- 1.

[15] PLOG, S. Leisure Travel: A Marketing Handbook. Upper Saddle River, NJ: Prentice-Hall, 2004. ISBN 9780130493170.

[16] PORTER, M. E. Konkurenčná výhoda. Praha: Victoria Publishing, 1985. 626 s. ISBN 80-85605$12-0$.

[17] PORTER, M. E. Clusters and New Economies of Competition. Harvard Business Review, 1998, Nov/Dec, s. 77-90.

[18] PORTER, M. E. (2000a). Location, competition, and economic development: local clusters in a global economy. Economic Development Quarterly, 2000, 14 (1), s. 15-34.

[19] PORTER, M. E. et al. Regions and New Economics of Competition. In Scott, A.J. Global City Regions. Blackwell Oxford, 2001s. 139-152.

[20] SAMUELSON, P. A.; NORDHAUS, W. D. Economics. Boston: Irwin McGraw, 1995. ISBN 007-054981-8.

[21] SMERAL, E. In Peter Keller, Thomas Bieger. Fundamentals and Concepts for Achieving growth and competitiveness. Berlin: Erich Schmidt Verlag GMbH\&Co, 1996. ISBN 9783503103430.

[22] THODE S.F.. MASKULKA J. M. Place-based marketing strategies, brand equity and vineyard valuation. Journal of Product and Brand Management, 1998, 7(5), s. 379-399.

[23] VAŇOVÁ, A. Strategické marketingové plánovanie rozvoja územia. Banská Bystrica: ekonomická fakulta UMB, 2006, 140 s. ISBN 80-8083-301-X.

[24] VARIAN, H. R. Microeconomics. A Modern Approach. New York: W.W. Norton \& Company, 2010. ISBN 978-0-393-93424-3. 